\title{
Euronext Borsalarının Sermaye Piyasası Araçlarına Göre Borsa Performansının Analizi: VIKOR Yöntemi Uygulaması
}

Hașim BAĞCl'

Makale Gönderim Tarihi: 20.05.2019

Makale Kabul Tarihi: 16.03.2020

\section{Öz}

Bu çalıșmada Euronext Borsaları'nın kendi içerisindeki dinamik yapıyı görmek adına; 2004-2017 yılları arası 18 yıllık dönemi kapsayan ve borsaların ișlem günü sayısı ve borsalarda ișlem gören sermaye piyasası araçları tutarına göre Euronext Borsaları'ndan hangisinin hangi yılda daha üstün performans gösterdiği ve daha etkin olduğu belirlenmiștir. Bu tespiti gerçekleștirmek için Vıkor yöntemi tercih edilmiștir. Analiz sonucunda; Amsterdam Borsası'nın Euronext'te en etkin borsa olduğu ve Dublin Borsası'nın ise Euronext içerisinde en düșük performans gösteren borsa olduğu saptanmıștır.

Anahtar Kelimeler: Dünya Borsaları, Euronext, Vıkor Yöntemi

Jel Sinıflandırması: G1 1, G15, G34

1 Dr. Öğretim Üyesi, Aksaray Üniversitesi Sağlık Bilimleri Fakültesi Sağlık Yönetimi Bölümü, hasimbagci1907@hotmail.com, Orcid ID: 0000-0002-5828-2050 


\section{Analysis Of Stock Market Performance According To Capital Market Instruments Of Euronext Stock Exchange: Application Of Vıkor Method}

\section{Abstract}

In this study, Euronext Stock Exchanges were examined with the data included 18 years, between 2004-2017 period in order to investigate dynamic structure. According to the number of trading days and the amount of capital market instruments traded on the stock exchanges, it was determined which of the Euronext Exchanges performed best and which was the most effective. The Vıkor method was chosen to servet this purpose. As a result of the analysis; it was found that the Amsterdam Stock Exchange was the most effective stock exchange in Euronext and the Dublin Stock Exchange was the lowest-performing stock in Euronext.

Keywords: World Exchanges, Euronext, Vıkor Method

Jel Classification: G11, G15, G34

\section{Giriș}

Borsalar, birçok farklı ișlemin sistemli bir biçimde gerçekleștiği ve gerçekleșen bu ișlemlerin belirli amaçlar ve kurallar doğrultusunda yapıldığı mekânlardır. Piyasalardaki farklı yapıdan dolayı, borsaların amacı her ülke için değișiklik göstermektedir. Finansal piyasalar ise fon fazlası olanlar ve fon ihtiyacı olanları bulușturan aralarında fon transferi sağlayan sistemli bir yapıdan ibarettir. Finansal piyasaların sistemli bir yapıya sahip olmasının; çıkar çatıșmasını önleme, tarafların haklarını koruma ve ülkedeki etkin kaynak dağılımını sağlama gibi olumlu etkileri bulunmaktadır. Sermaye piyasası ise fon arzı, yatırımcı ve piyasa üçgeninden olușan bir sistemden olușmaktadır. Yatırımcı ve piyasa arasındaki bağlantıyı sağlayan; aracı kurumlar ve kurumsal yatırımcılardır. Piyasalar, çok sayıda değișkenin varlığı ve birbirleriyle sürekli etkileșimde olması nedeniyle çok dinamiktir ve sürekli değișim halindedir. Bu dinamizm nedeniyle çıkar çatıșmaları, șeffaflık, dürüst ve doğru bilgi aktarımı gibi problemler ortaya çıkmaktadır (Lee, 1992, s. 4).

Sermaye piyasaları 20. yüzyıldan itibaren gelișme göstermeye bașlamıș ve ülkelerin sanayilerinin gelișimine katkıda bulunmuștur. Küreselleșmeyle birlikte sermaye piyasaları, ülkelerin bağımsızlıklarını kazanmalarında, kalkınma ve büyümelerinde bașlıca rol oynamaktadır. Sermaye piyasaları, ekonomik kaynakların etkin bir șekilde kullanımını 
ve aktarımını sağlayarak ülkelerin ekonomik performanslarını yükseltmektedir. Ancak kaynakları yetersiz olan ülkeler ise krize doğru sürüklenmektedir. 21. yüzyılda ise sermaye piyasaları bütünleșerek birçok piyasa yerine daha az ancak çok güçlü piyasalar olarak varlığını sürdürmektedir. Bu piyasaların en önemli hedefi; sermayenin serbest dolașımını sağlamaktır (Seymen Oskay vd., 2006, s. 182).

Piyasaların gelișmesi ve finansın uluslararası nitelik kazanmasıyla beraber yeni finansal ürünler piyasaya çıkmıș, uluslararası finansal kurum ve kurulușlar olușturulmuș, finansal hizmetlerin kalitesi artmıș, sermaye maliyeti düșmüș, sermayenin dolașım hızı artmıș ve bütün bu gelișmeler rekabeti iyice artırmıștır. Rekabetin artıșı, piyasa hacimlerinin büyümesini sağlamıștır. Yeni finansal yapı birtakım olumsuz özellikleri de içerisinde barındırmaktadır. Bunlar; ekonomik istikrarsızlık ve belirsizlik artıșıdır. Bu nitelikler, gelișmiș ülkeler için fırsat iken az gelișmiș ve gelișmekte olan ülkeler için tehdit unsuru tașımaktadır. Çünkü gelișmiș ekonomilerin diğer ülke ekonomileri üzerinde gücünü hissettirdiği yeni bir finansal sistem olușmaktadır (Hamurcu ve Aslanoğlu, 2013, s. 28-29). Yeni finansal sistemde ekonomik ve ticari sınırlar ortadan kalkmıștır. Bunun sonucu olarak dünya ülkelerinin borsaları birbirlerine karșı hassas olmuș ve bir borsadaki gelișme diğer borsayı etkilemiștir. Dolayısıyla borsalar arası etkileșim sonucu yatırımcılar sorunlu borsalardan yatırımlarını hızla çekmektedir. Çünkü olumsuz yatırım koșulları diğer borsaların finansal sistemine yayılmakta ve finansal bulașıcılık adı verilen kavram ortaya çıkmaktadır.

Bu çalıșmada dünyadaki borsaların gelișimini görmek ve dünya borsalarında hangi sermaye piyasası aracının ne miktarda kullanıldığını incelemek amaçlanmıștır. Bu amacı gerçekleștirmek için Avrupa borsalarının durumu incelenmiștir. Avrupa borsaları Euronext adı altında birleștirilmiș birçok borsadan olușmaktadır. Çalıșmanın gerçekleștiği dönemde aktif olarak faaliyetlerini sürdüren; Euronext Paris, Euronext Amsterdam, Euronext Lizbon, Euronext Dublin ve Euronext Brüksel Borsalarıdır. Bu borsaların 2004-2017 yılları arasını kapsayan 14 yıllık zaman diliminde yıllık verileri yardımı ile borsa performansları ölçülmüștür. Bunun nedeni; kullanılan yöntemlerin yıllık verilerle istatistiksel analize daha uygun olması ve Euronext'te aylık verilere ulașılamamasıdır. Ayrıca veri setinin 14 yıl olmasının nedeni ise yıl sayısını çoğaltarak daha keskin sonuçlar bularak borsalar arası kıyaslamayı daha net yapabilmektir. Euronext Borsaları́nın performans ölçümü, sermaye piyasası araçları yardımıyla yapılmıștır. Çünkü borsada ișlem gören sermaye piyasası 
araçlarının etkinliğini de görebilmek hedeflenmiștir. Elde edilen verilerle borsa performansını ölçebilmek için çok kriterli karar verme tekniklerinden olan Vıkor yöntemi tercih edilmiștir. Yöntemin seçilme sebebi; Vıkor yönteminin hem güncel bir yöntem olması hem de yöntemin güvenilir olmasıdır. Bu önerinin savı, yöntemin kurucusu olan Opricovic (1998) tarafından ve Vıkor yönteminin așamaları içerisinde belirtilen; analizin sona ermesinin ardından avantaj ve istikrar gibi koșullarla tekrar kontrol edilmesi ve koșulların sağlanmamasının yapılan analizi geçersiz kılmasıyla desteklenmektedir (Opricovic ve Tzeng, 2004).

\section{Dünya Borsaları}

Dünyada borsaların geçmișinin savașlardan elde edilen ganimetlere dayandığı ileri sürülmektedir. Roma İmparatorluğu bu ganimetler sayesinde sermayenin bașkenti haline gelmiș ve M.Ö. 180 yılında ilk menkul kıymet borsası Roma'da kurulmuștur. Roma İmparatorluğu'nun yıkılmasıyla sona ermiștir. Avrupa'da ilk resmi borsa Paris'te bir köprüde bașlamıștır. Özel bir binada ilk borsa ise Belçika'nın liman șehri olan Anvers'te kurulmuștur. İngiltere'de ilk borsa ise Kraliyet Borsası olarak kurulmuștur. 17., 18. ve 19. yüzyıllarda dünyanın önemli borsalarından olan Berlin, Viyana, New York, Brüksel, Milano, Roma, Madrid, Tokyo ve İstanbul borsaları faaliyete geçmiștir. Zaman ilerledikçe her ülkede borsalar artmaya bașlamıștır. Amerika, Japonya, Kanada, Fransa, Almanya, İsviçre, Avustralya gibi ülkeler birçok borsanın aktif olduğu ülkelere örnek olarak verilebilmektedir (Fertekligil, 2000, s. 1). Dünyada en çok ișlem hacminin olduğu ve mükemmel borsalar olarak adlandırılabilecek borsalar: New York ve Tokyo Borsalarıdır. Ayrıca dünyada ișlem hacmi ve piyasa değerine göre belirlenen ilk 20 borsa hakkındaki bilgiler Tablo 1'de verilmiștir. 
Tablo 1. Dünyanın ilk 20 Borsası

\begin{tabular}{|c|c|c|c|c|}
\hline Borsa Adı & Bölge & Piyasa Alanı & $\begin{array}{c}\text { Piyasa } \\
\text { Değeri (\$) }\end{array}$ & $\begin{array}{l}\text { Açilıș-Kapanıs } \\
\text { Saatleri }\end{array}$ \\
\hline New York & $A B D$ & New York & 30923 & $09: 30-16: 00$ \\
\hline Nasdaq & $A B D$ & New York & 10857 & $09: 30-16: 00$ \\
\hline Japonya & Japonya & Tokyo & 5679 & $09: 30-15: 00$ \\
\hline Shanghai & Çin & Shanghai & 4026 & $09: 30-15: 00$ \\
\hline Hong Kong & Hong Kong & Hong Kong & 3936 & $09: 15-16: 00$ \\
\hline Euronext & Avrupa Birliği & $\begin{array}{l}\text { Amsterdam, Brüksel, } \\
\text { Dublin, Lizbon, Paris }\end{array}$ & 3927 & $09: 00-17: 30$ \\
\hline Londra & İngiltere & Londra, Milano & 3767 & $08: 00-16: 30$ \\
\hline Shenzhen & Çin & Shenzhen & 2504 & 09:30-15:00 \\
\hline TMX & Kanada & Toronto & 2095 & $09: 30-16: 00$ \\
\hline Bombay & Hindistan & Mumbai & 2056 & $09: 15-15: 30$ \\
\hline $\begin{array}{l}\text { Hindistan Ulusal } \\
\text { Borsası }\end{array}$ & Hindistan & Mumbai & 2030 & $09: 15-15: 30$ \\
\hline Deutsche Börse & Almanya & Frankfurt & 1864 & $08: 00-22: 00$ \\
\hline SIX Swiss & İsviçre & Zürih & 1523 & $09: 00-17: 30$ \\
\hline Kore & Güney Kore & Seul & 1463 & $09: 00-15: 30$ \\
\hline İzlanda & İzlanda & İzlanda & \multirow{8}{*}{1372} & 09:30-15:30 \\
\hline Ermenistan & Ermenistan & Ermenistan & & 10:00-15:00 \\
\hline Kopenhag & Danimarka & Kopenhag & & 09:00-17:00 \\
\hline Stockholm & İsveç & Stockholm & & $09: 00-17: 30$ \\
\hline Helsinki & Finlandiya & Helsinki & & 10:00-18:30 \\
\hline Talin & Estonya & Talin & & 10:00-16:00 \\
\hline Riga & Letonya & Riga & & 10:00-16:00 \\
\hline Vilnius & Litvanya & Vilnius & & 10:00-16:00 \\
\hline Avustralya & Avustralya & Sidney & 1326 & 10:00-16:00 \\
\hline Taiwan & Tayvan & Taipei & 966 & $09: 00-13: 30$ \\
\hline B3 & Brezilya & Sao Paulo & 938 & 09:00-18:00 \\
\hline JSE Limited & Güney Afrika & Johannesburg & 894 & 09:00-17:00 \\
\hline $\begin{array}{l}\text { Bolsas y Mercados } \\
\text { Espanoles }\end{array}$ & İspanya & Madrid & 764 & $09: 00-17: 30$ \\
\hline
\end{tabular}

Kaynak: World Federation of Exchanges, 2018

Tablo 1'de dünyanın ișlem hacmi ve piyasa değeri açısından dünyanın en büyük ilk 20 borsası gösterilmiștir. Tabloya göre; dünyanın 
en büyük borsaları New York Borsaları'dır. Ayrıca bazı borsalar piyasa değeri eșit olduğu için aynı sırada yer almaktadır. Bunlar: İzlanda, Ermenistan, Kopenhag, Stockholm, Helsinki, Talin, Riga ve Vilnius Borsalarıdır. Dünya borsalarının faaliyet gösterdiği alanlar ise genellikle ülkelerinin bașkentleri veya finans merkezleridir. Yerel saatlerine göre verilen açılıș-kapanıș saatleri incelendiğinde; dünyanın en uzun süre açık borsası Frankfurt Borsası iken en az açık borsa ise Tayvan Borsası'dır. Bu bilgiler yatırımcılar açısından dünya borsalarının genel hatları olarak özetlenmiștir.

Dünya borsalarında; birleșme, ișbirliği, ortaklık ve devralma gibi birtakım olaylarla birkaç borsanın birlikte hareket etmesi gerçekleșebilmektedir. Borsaların stratejik amaçlı yaptıkları anlașmalar; ișlem maliyetini azaltmak ve yeni yatırımcılara ulașabilmek gibi nedenlerden dolayı yapılmaktadır. Stratejik amaçlı yapılan bu birleșme vb. faaliyetler ulusal bazda gerçekleșebildiği gibi uluslararası olarak da yapılabilmektedir. Ulusal bazda yapılan birleșmelere örnek olarak; Toronto, Singapur, Endonezya, Zagrep, Bükreș, İsviçre ve CME group verilebilir. Bu șehirlerde, aynı ülkedeki borsalar birbiriyle birleșerek tek bir borsa altında toplanmıștır (Çikot, 2008, s. 8-12).

Diğer bir boyut ise çalıșmanın ana örneklemini olușturan gruptaki gibi uluslararası birleșmeleri ifade etmektedir. Bu birleșmelerin birçok örneği bulunmakta, bu örneklerin bir kısmı stratejik ortaklık biçiminde bir kısmı ise devralma ve birleșme șeklindedir. Stratejik ortaklıklara așağıdaki olaylar örnek olarak verilebilir (Chemmanur ve Jie, 2008, s. 78):

- Temmuz 1998'de Londra ve Frankfurt Borsaları birleșerek her hissenin her iki borsada geçerli tek fiyat üzerinden ișlem göreceği bir borsa ortaklığı gerçekleștirmișlerdir.

- Ocak 1999'daki Norex adı verilen Kopenhag ve Stockholm Borsaları'nın ortak bir ticaret sistemi uygulamak için uyguladıkları bir anlașmadır. Illerleyen dönemde Norex'e İzlanda ve Oslo Borsaları da dahil edilmiștir.

- Kasım 2000'de Newex adı verilen Viyana merkezli sadece Doğu Avrupa'ya hitap eden bir borsa açılması planlanmıș ve bu borsalar Viyana-Frankfurt Borsalarının birleșiminden olușmuștur. 
- Mayıs 2004'te Viyana Borsası'nın Budapește Borsası́nın \%68'ini satın almasıyla Viyana-Budapește Borsaları ortaklığı kurulmuștur.

- Ocak 2007'de New York Euronext Borsası ve Tokyo Borsası karșılıklı ișbirliği anlașmasıyla küresel trendlerden birbirlerini haberdar etmișler ve gerektiğinde personel değișiminde bulunmușlardır.

- Ocak 2008'de Tokyo ve Abu Dhabi Borsaları aralarındaki anlașma gereği; hem ticareti geliștirmek hem de finansal ürün çeșitliliğini artırmak için stratejik ortaklık kurmușlardır. Bu anlașma, Tokyo'nun sınır ötesi yatırımları teșvik etmek amacıyla Orta Doğu pazarına yönelik yapmıș olduğu ilk anlașmadır.

Borsalar stratejik ortaklıklar dıșında daha kalıcı bir çözüme gitmek için birleșme yoluna da gidebilirler. Geçmiște birden çok borsanın görüșmesiyle karara bağlanan birleșme örnekleri verilmiștir (Chemmanur ve Jie, 2008, s. 79):

- Mayıs 2000'de Londra ve Frankfurt Borsaları IX olarak adlandırılan yeni bir șirket kurma planı hedeflemiștir. Hatta bu șirketin elektronik ticaret platformu olarak Xetra'nın kullanılacağı ifade edilmiș; ancak İsveç'in bu șirketi devralma çabaları sonucu, birleșme planı geri çekilmiștir.

- Aralık 2005'de Euronext ve Frankfurt Borsaları riskten korunmak için bir görüșme gerçekleștirmișlerdir. Ancak Euronext Borsası'nın hissedarları Frankfurt Borsası'ndan gelen birleșme tekliflerini çıkarlarını ihlal ettiği için reddetmișlerdir.

- Mayıs 2006'da New York Borsası, Euronext Borsası'yla birleșmek için teklifini iletmiș; yapılan görüșmelerde Euronext hissedarlarının bir kısmının karșı çıkmasına rağmen Aralık 2006'da olumlu șekilde sonuçlanmıștır. Mart 2007'de Euronext hisselerinin \% 91,4'ü New York Borsası tarafından satın alınarak 4 Nisan 2007'de New York Euronext Borsası olarak piyasalara giriș yapmıștır.

- Haziran 2007'de Londra ve İtalya Borsaları birleșme için görüșme gerçekleștirmișler ve ardından Londra Borsası İtalya'nın Milano Borsası́nın 2.3 milyar dolarlık kısmını satın almıștır. Bu birleșme; Londra Borsası'nın tarihinde ilk kez FTSE 100 (Fi- 
nancial Times and Stock Exchange 100) endeksine girmesini kolaylaștırmıștır.

- Ocak 2008'de New York Euronext Borsası ve Amerikan Borsası (AMEX) arasında satın alma anlașması imzalanmıștır. New York Euronext, Amex Borsası'nı 260 milyon dolar karșılığında satın almıștır. Anlașmanın amacl; New York Euronext Borsası'nın fon alımlarını destekleyerek hızlı büyümesini sağlamak ve Amerika Opsiyon Borsası'nda zirvelere çıkarmaktır.

Stratejik ortaklıklar ve birleșmelerin bir kısmı geçici bir kısmı ise kaIıcı anlașma niteliği tașımaktadır. Bu nedenle borsalar belirli dönemlerde piyasalarda yükseliș gösterebilmek ve birden çok ülkeye hitap edebilmek için bu anlașmaları yapabilmektedir. Dünyada ilk 20 borsa içerisinde birden çok piyasaya hitap eden iki borsa bulunmaktadır. Bunlar; Londra ve Euronext Borsaları'dır. Londra Borsası; faaliyet gösterdiği alan olan Londra dișında İtalya'daki Milano piyasasında aktiftir. Euronext Borsası ise Avrupa Birliği'nin borsası olduğu için, Avrupa'nın en önemli șehirlerinden olan Amsterdam, Lizbon, Paris, Dublin ve Brüksel'de finansal aktivitelerini sürdürmektedir. Bu çalıșmada birden çok ülkede faaliyet gösteren ve Avrupa'nın finans kaynağı olan Euronext Borsası incelenmiștir.

\section{Euronext Borsası}

Euronext Borsası; 22 Eylül 2000'de Amsterdam, Brüksel ve Paris Borsaları'nın birleșimiyle kurulan ve merkezi Paris'te olan bir borsadır. Euronext Borsası ilerleyen yıllarda giderek büyüyerek varlığını devam ettirmiștir. 2002 yılında Euronext, Londra Uluslararası Finansal Vadeli İșlemler ve Opsiyon Borsası (LIFFE)'yi satın almıștır. Ayrıca 2002 yılında Lizbon Borsası Euronext'e katılmıștır. Euronext; borsaların bir iș ortaklığı değil, borsaların birleșiminden ibarettir. Euronext; Avrupa'da ortak bir pazar olușturmak, aynı para birimini kullanmak (Euro) ve ișlem maliyetini azaltarak likidite havuzu olușturmak amaçlarıyla kurulmuștur. Euronext Borsaları'nda sadece hisse senedi değil, tahvil bono ve türev araçlar gibi finansal ürünler ișlem görmektedir. Euronext'te ișlem görecek finansal ürünlerin Euronext Borsaları'ndan Paris, Brüksel, Amsterdam ve Lizbon'daki borsalardan birine kayıtlı olması gerekmektedir (Kırca, 2000, s. 14; Coșkun, 2002, s. 77).

Euronext'in ilk birleșme safhası; 3 borsanın șirketleșme sürecini tamamlamasının ardından gerçekleșmiștir. 3 borsanın da Avrupa Birliği kurallarına uygun biçimde sermaye piyasalarını düzenlemesi șirketleș- 
menin temel koșullarından biridir. Birleșme yönetim kurulu tarafından yapılmıș ve 3 borsadaki hisse sahipleri mevcut hisselerini Euronext hisseleriyle takas etmișlerdir. Euronext hisselerinin birleșme gerçekleștikten sonra ilk halka arzı 21 Haziran - 4 Temmuz 2001 arasındaki zaman diliminde gerçekleșmiștir. Hisselerin ilk ișlem gördüğü gün ise 6 Temmuz 2001'dir (Dilbaz, 2007, s. 99-101).

Euronext Borsası 2007 yılında Avrupa kıtasını așarak büyümeye devam etmiștir. 4 Nisan 2007'de Euronext hisselerinin \%97'si New York Borsası'na satılmıștır. Yeni olușan borsa, New York Euronext Borsası (NYSE Euronext veya NYX) ismini almıștır. NYX; dünyadaki ilk kıtalararası borsa özelliğine sahip, 6 ülkeye hitap eden ve yatırımcılara oldukça farklı finansal ürün ve hizmetler sunan dünyanın en büyük likit borsasıdır. Euronext Borsası bu birleșimden sonra büyümeye devam etmiș, Mart 2018'de İrlanda Borsası'nı satın almıș ve yeni ismini Euronext Dublin olarak dünyaya tanıtmıștır. Mevcut durumda; NYX ya da NYSE Euronext Borsaları'nın ortaklık yapısında; Amsterdam, Brüksel, Lizbon, Paris, New York ve Dublin Borsaları yer almaktadır. Böylece Euronext 7 ülkede faaliyet gösteren bir borsa haline gelmiștir ve bu ülkeler: İngiltere, $A B D$, İrlanda, Fransa, Belçika, Portekiz ve Hollanda'dır (Euronext, 2019; Budak ve Çikot, 2011 , s. 82-88). Euronext Borsaları'nın olușumu ve içeriği Șekil 1'de gösterilmiștir.

\section{Șekil 1. Euronext Borsalarının Olușumu}

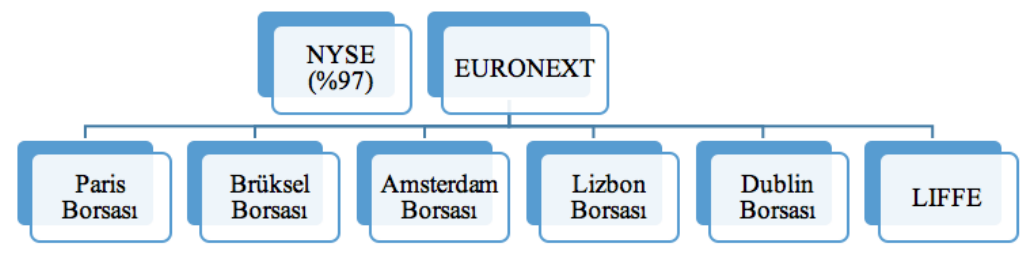

Kaynak: Euronext, 2019

Șekil 1'de görüldüğü üzere Euronext Borsası; 5 ulusal borsa ve 1 Liffe olmak üzere 6 Avrupa Borsası'ndan olușmaktadır. Ancak NYSE, Euronext'in neredeyse tamamına (\%97) sahip olduğu için diğer Euronext Borsaları'na hakim ve Euronext'in sahibidir. Ayrıca NYSE; Euronext'in diğer kıtalara açılmasına öncülük eden borsadır.

Euronext Borsaları; finansal araçların kayıt alına alınması, menkul kıymet ișlemleri, takas-mutabakat ișlemleri, piyasa verilerinin yayınlanıp- 
duyurulması ve teknolojik destek gibi konularda birçok hizmet sunmaktadır. Ayrıca Euronext'te; spot ve vadeli piyasa olmak üzere bașlıca 2 piyasa bulunmaktadır. Spot piyasa, Euronext; vadeli piyasa Euronext. liffe olarak ifade edilmektedir. Bu piyasalarda ișlem yapan Euronext müșterileri; finansal kurumlar, borsaya kayıtlı firmalar, bireysel ve kurumsal yatırımcılar, diğer kurum-kurulușlar ve finansal bilgi kullanıcılarından olușmaktadır (Emre, 2005, s. 7-17).

\section{Literatür İncelemesi}

Yerli literatürde dünya borsaları ile ilgili çalıșmalar mevcut iken doğrudan Euronext Borsaları́nı inceleyen çalıșma bulunmamaktadır, yabancı literatürde Euronext Borsaları'nı inceleyen çalıșmaların bir hayli fazla olduğu gözlenmektedir.

Plantinga ve Scholtens (2001) çalıșmalarında Euronext Borsaları́nın fon yönetimi stillerini analiz etmișlerdir. Özellikle sosyal sorumluluğun nasıl hesaplandığı araștırılmıștır. 1990'larda Hollanda, Belçika ve Fransa'daki fon performansını değerlendirmek için 800'den fazla yatırım fonundan yararlanarak stil analizi kullanılmıșıı. Analiz sonucunda; sosyal sorumluluk endekslerini bir dereceye kadar yansitan fonların, sosyal sorumluluk sahibi yatırım stratejileriyle hiçbir ilișkisi olmayan fonlardan daha iyi performans gösterdiği tespit edilmiștir.

Beltran, Durre ve Giot (2004) Euronext Borsaları'nda likidite ve volatilite ilișkisini incelemișlerdir. Bu ilișkiyi belirlemek için 2 Aralık 2002-30 Nisan 2003 tarihleri arasındaki günlük verilerden yararlanımıștır. Ölçümü gerçekleștirmek için VAR analizi kullanılmıștır. Analizin sonucunda; likidite ve volatilite arasında temel anlamda farklılığın az olduğu; ancak yüksek volatilite düzeyinde sert likidite düșüșü yașandığı görülmüștür.

Floros, Jaffry ve Lima (2007) çalıșmalarında Lizbon Borsası'nın Euronext'e girmeden önceki durumuyla girdikten sonraki durumunu (fraktal yapısını) araștırmıșlardır. 4 Ocak 1993-13 Ocak 2006 birleșmeden önceki dönem ile 1 Șubat 2002-13 Ocak 2006 birleșmeden sonraki dönemi içeren günlük veriler örneklemin veri setini olușturmaktadır. Araștırmada ARFIMA, GARCH ve ARFIMA-FIGARCH modelleri kullanımıștır. Lizbon Borsası'nın Euronext'e üye olduktan sonra fraktal yapısının bozulduğu ve etkinlik düzeyinin arttığı bulgularına saptanmıștır.

Pownall, Vulcheva ve Wang (2011) 4 Avrupa ulusal borsasının Euronext ile birleșmesinin finansal raporlama kalitesi ve likiditedeki etki- 
lerini araștırmıșlardır. Birleșme sonrası muhasebe sektöründe kalite artıșı ve piyasa șirketlerinin kazancının sektörel bazda değil firma bazında gerçekleștiği belirlenmiștir. Sonuçlar; borsa birleșmelerinin daha yüksek raporlama kalitesi ve açıklamayla birlikte gerçekleșebileceğini ve birleșme birimlerinin daha geniș bir yatırımcı müșterisine maruz kalarak firmaların finansal raporlamaları ve likiditeleri üzerinde olumlu etkileri olabileceğini ortaya koymaktadır.

Isola, Teixeira ve Ferreira (2014) araștırmalarında; mevcut küresel finansal krizin etkilerini içeren bir dönemde (1990-2010) Euronext Lizbon listesindeki șirketlerde ilk düșük fiyat seviyesini belirlemeyi amaçlamıștır. Ölçüm için; piyasa tarafından düzeltilmiș anormal getiriler ve al-bekle anormal getirileri kullanılmıștır. Sonuç olarak; hem kısa hem uzun vadede ilk halka arz için düșük fiyatın verimlilik düșüklüğünden kaynaklandığı ortaya konmuștur.

Brodocianu (2015) ARCH modeliyle CAC40 Ulusal endeksi ve Euronext 100 PAN endesklerini kullanarak her iki endeksin yatırım davranıșlarını kıyaslamıșlardır. Çalıșmada çeșitlendirme yapılmasının nedeni; getirileri artırmak ve riski azaltmaktır. Bu doğrultuda; Avrupa yeni finansal mimarisiyle birlikte son 10 yılda CAC 40 endeksinin ve Euronext 100 endeksinin davranıșını karșılaștırmak, iki endekse yapılan ortak yatırımları belirlemek ve ekonometrik bir model olușturmak amaçlanmıștır. Çalıșmada her iki dizi için de EGARCH modeli seçilmiștir. Finansal entegrasyon nedeniyle, ulusal bir pazarda ortaya çıkan bir șokun Avrupa pazarında da yankılarının olduğu sonucuna ulașılmıștır.

Matos ve Coelho (2016) Euronext Lizbon Borsası'ndaki miyopik davranıș ve borsanın kısa vadeli olmasından kaynaklanan piyasa verimsizliğini incelemișlerdir. Verimsizlik; yatırımcıların hem kısa vadeli hem de uzun vadeli kazançlarının değer kaybettiği bir durumdur. Bu çalıșmada; Portekiz borsalarının, 2000 ve 2008 yılları arasındaki kısa vadeli kazançlar için böyle bir tercih gösterip göstermediğini incelenmiș ve fiyatların defter değeriyle nasıl ilișkili olması gerektiğine dair tahminler üreten Abarbanell and Bernard (2000) muhasebe tabanlı değerleme modelini kullanarak kısa ve uzun vadeli kazançlar tahmin edilmeye çaIıșılmıștır. Aslında, Abarbanell and Bernard (2000) enine kesit analizine dayanarak bu dönem için toplanan kanıtlar pazar verimliliğini desteklediğinden, pazar miyopisi iddiası reddedilmiștir. Bu sonuca göre, Portekiz borsaları listelenen șirketlerin tüm değer bileșenleri için aynı ağırlığı tahsis etmektedir. Yenilikçi bir panel veri analizine dayanarak, 
yatırımcıların defter değerini ve kısa vadeli kazancı etkin bir șekilde değerlendirebildiği, ancak pazarın uzun vadeli kazancını düșürdüğü için, piyasanın belirli bir kısa vadeli olma biçimine sahip olduğuna dair bulgulara ulașilmıștır.

Than (2017) Euronext Borsası'nda fiyat kümelenmesinin belirleyicilerini tespit etmiștir. İșlem hacmi ve varlık fiyatı gibi açıklayıcı değișkenlerin kanıtlarının, bilgi maliyetlerini azaltmak için kullanıldığı, fiyat kümelenmesi üzerinde olumlu ve istatistiksel olarak önemli bir etkisi olduğu saptanmıștır. Bununla birlikte, Lizbon hariç diğer üç borsa için volatilite ile fiyat kümelenmesi arasında negatif bir ilișki olduğu görülmüștür. Bu durum; yüksek volatilitenin, bilgili tüccarların egemen olduğu Amsterdam ve Paris gibi büyük borsalar için daha yüksek fiyat kümelenmesine yol açmadığını göstermekte iken fiyat keșif sürecini iyileștirebileceklerinden ve daha iyi bilgilendirildiklerinden dolayı belirsizliği azaltmaktadır. Lizbon gibi daha küçük borsalar için ise daha küçük ișlem büyüklüğü ile bilgi sahibi olmayan yatırımcılar ve diğer davranıșsal önyargılar nedeniyle fiyatın en yakın sayıya yuvarlama eğiliminin daha fazla görüldüğü belirlenmiștir.

Desagre, D'Hondt ve Petitjean (2018) CAC40 hisse senetlerinin tüm sipariș ve ișlem verilerinden faydalanarak 2002-2006 yılları arasında Euronext'teki hızlı ișlemlerin likiditeyi nasıl etkilediğini incelemișlerdir. 2006 yılında piyasa faaliyetlerinin daha yoğun olduğu ve siparișlerin daha yüksek oranda iptal edildiği görülmüștür. Hisse senetleri arasındaki eșitsizliğe rağmen; 2002'den 2006'ya doğru oynaklık ve yayılmalar azalırken, derinlik artmıștır. Ayrıca piyasa üyelerinin kimlik kodları yardımıyla, 2006 yılında mesaj trafiğine ve siparișlerin ömrüne göre hızlı ișlemciler tespit edilmiștir. 2006 yılında hızlı ișlem gören hisse senetlerinin likidite artıșından en az fayda sağladığı belirlenerek çalıșma sonlandırılmıștır.

Literatür incelemesi sonucunda Euronext Borsaları'nın etkinliği, verimliliği, performansı ile ilgili çalıșmaya rastlanmamıștır. Dolayısıyla literatüre katkı sağlamak ve Euronext Borsaları'nın hangisinin borsa performansının daha iyi olduğunu tespit etmek amacıyla bu çalıșma gerçekleștirilmiștir.

\section{Araștırmanın Yöntemi}

Yapılan araștırmada Euronext Borsaları'nın borsa performansı incelemesi yapılırken sermaye piyasası yatırım araçları baz alınmıștır. Araștırmanın analizini yapabilmek için çok kriterli karar verme teknikle- 
rinin kullanılması gerekmektedir. Çünkü hem kriter hem alternatifi bütünleștirerek kıyaslama yapabilen yöntemler çok kriterli karar verme yöntemleridir ve Vıkor yöntemi ekonomi ve finans alanında kullanımını öneren; Özden (2012), Karaatlı, Ömürbek ve Köse (2014), Paksoy (2015), Tezergil (2016), Çalıșkan ve Eren (2016) ve Altay Topçu ve Oralhan (2017) gibi çalıșmalar literatürde bulunmaktadır. Araștırmada bu yöntemler içerisinde; sonuçları sağlıklı ve güvenilir olan Vıkor yöntemi tercih edilmiștir. Bunun temel nedeni; Vıkor yönteminin sonuçlarının iki așamayla birlikte tekrar kontrol edilmesi ve eğer iki așamaya ait koșullar sağlanmıyorsa o döneme ait performans sıralaması yapamamasıdır.

\section{Vıkor Yöntemi}

Vıkor yöntemi; Opricovic tarafından 1998 yılında geliștirilen bir yöntem olup, yöntemin ismi: Vise Kriterijumska Optimizacija I Kompromisno Resenje (çok kriterli kompleks sistemlerin optimizasyonu) kelime grubunun harflerinden olușmaktadır. Vıkor yöntemi literatürde yeni kullanılan çok kriterli karar verme yöntemlerinden biridir. Hemen hemen tüm çok kriterli karar verme tekniklerinden olduğu gibi alternatiflerin değerlendirme faktörlerine göre kıyaslanmasını göstermektedir. Bu yöntem; ekonomi, finans, üretim, pazarlama, eğitim, mühendislik, lojistik, spor ve teknoloji gibi birçok alanda kullanılmaktadır. Bu alanlardaki çalıșmalara; Akyüz (2012), Ömürbek, Karaatlı ve Yetim (2014), Karaatlı, Ömürbek ve Köse (2014), Ertuğrul ve Özçil (2014), Demircanlı ve Kundakcı (2015), Ay Türkmen ve Bildik (2015), Paksoy (2015), Tezergil (2016), Çalıșkan ve Eren (2016), Yıldırım, Kuzu ve Özdemir (2016), Altay Topçu ve Oralhan (2017) ve Yavuz ve Baki (2019) tarafından yapılan çalıșmalar örnek olarak verilebilir.

Yöntemin uygulanması için gerekli așamalar sırayla gösterilmiștir (Opricovic ve Tzeng, 2004, s. 447).

Adım 1: Tüm değerlendirme faktörlerinin en iyileri ve en kötüleri 1 numaralı denklemde görüldüğüüzere seçilmektedir.

$$
F_{i}^{*}=\max _{i j} \quad F_{i}=\min f_{i j}
$$

Adım 2: Belirlenen ağırlıklar bağlamında $S_{i}$ ve $R_{i}$ değerleri 2 ve 3 numaralı formüllerle hesaplanmaktadır.

$$
\begin{aligned}
& \mathrm{S}_{\mathrm{i}}=\sum \mathrm{W}_{\mathrm{i}}{ }^{*}\left(\mathrm{f}_{\mathrm{i}}^{*}-\mathrm{f}_{\mathrm{ij}}\right) /\left(\mathrm{f}_{\mathrm{i}}^{*}-\mathrm{f}_{\mathrm{i}}\right) \\
& \mathrm{R}_{\mathrm{i}}=\max _{\mathrm{i}}\left(\mathrm{W}_{\mathrm{i}}^{*}\left(\mathrm{f}_{\mathrm{i}}^{*}-\mathrm{f}_{\mathrm{ij}}\right) /\left(\mathrm{f}_{\mathrm{i}}^{*}-\mathrm{f}_{\mathrm{i}}\right)\right)
\end{aligned}
$$


Adım 3: Bu adımda $Q_{j}$ değerlerinin hesaplanmasıyla karar verme sürecine yaklașılmaktadır. $Q_{i}$ değerinin hesaplanmasında maksimum grup faydası kullanılmakta ve " $v$ " harfiyle sembolize edilmektedir. Maksimum grup faydası; $0 \leq v \leq 1$ aralığında değer almaktadır. Genellikle maksimum grup faydası değeri aksi belirtilmedikçe bir tarafa dengeyi bozmamak için $v=0,5$ değerini almaktadır. $Q_{i}$ değeri 4 numaralı formülle hesaplanmaktadır.

$$
Q_{i}=\left(v^{*}\left(S_{i}-S^{*}\right) /\left(S^{-}-S^{*}\right)\right)+\left((1-v) *\left(R_{i}-R^{*}\right) /\left(R^{-}-R^{*}\right)\right)
$$

Adım 4: $S, R$ ve $Q$ değerlerinin hesaplanmasının ardından alternatifler $S, R$ ve $Q$ değerlerine göre 3 ayrı biçimde küçükten büyüğe sıralanmaktadır.

Adım 5: Gerçekleștirilen sıralamanın kontrolünün yapılması ve koșulları sağlayıp sağlamadığının denetimidir. Bu așamada 2 koșul bulunmaktadır.

Adım 5.1: Kabul edilebilir avantaj koșulu: Bu koșul 5 ve 6 numaralı denklemler yardımıyla test edilmektedir.

$$
\begin{aligned}
& Q\left(a^{2}\right)-Q\left(a^{1}\right) \geq D Q \\
& D Q=1 / M-1
\end{aligned}
$$

5 numaralı formülde $Q$ değerine göre 2. en iyi alternatiffen birinci alternatif çıkarılarak ișlem yapılmakta ve bu sonucun DQ değerinden büyük olup olmadığı incelenmektedir. DQ ise 6 numaralı denklemde görüldüğü üzere bulunmakta ve buradaki $M$ değeri alternatif sayısını göstermektedir.

Adım 5.2: Karar vermede kabul edilebilir istikrar koșulu: Bu koșul; $S, R$ ve $Q$ değerine göre sıralanan alternatiflerin her birindeki sıralama incelenerek gerçekleștirilir ve $Q$ değerine göre yapılan sıralamanın $S$ ve $R$ değerlerindeki karșılıkları kontrol edilir, eğer $S$ veya $R^{\prime}$ nin herhangi birinde alternatif benzer sırada yer alıyorsa optimal çözüm kümesi olarak kabul edilir, aksi durumda çözüm kümesi dıșında yer almaktadır.

Bu koșullardan ikincisi sağlanamazsa çözüm kümesi $Q\left(a^{2}\right)$ ve $Q$ (a') alternatifleri olarak belirlenir; ancak ilk koșul sağlanamazsa tüm alternatifler çözüm kümesinde yer alır. Fakat bu alternatifler;

$$
Q\left(a^{n}\right)-Q\left(a^{1}\right) \geq 1 / M-1
$$

denklemine göre yeniden hesaplanmaktadır. 7 numaralı denklemdeki $Q\left(a^{n}\right)$ tüm alternatiflerin sayısını göstermektedir. Bu hesaplama araștır- 
madaki koșullara uyulup uyulmadığı tespit edilmektedir. Koșullara uyum Vıkor yönteminin sağlıklı ilerleyip ilerlemediğinin kanııdır.

\section{Araștırmanın Bulguları}

Araștırma 2004-2017 yılları arası 14 yıllık zaman dilimini kapsamakta ve örneklemi; Euronext Borsaları'ndan olușmaktadır. Euronext Borsaları olarak; Paris, Dublin, Lizbon, Amsterdam ve Brüksel Borsaları incelenmiștir. Çünkü Euronext Borsası'na kayıtlı 5 borsa bulunmaktadır. Ayrıca New York Borsası Euronext Borsaları'nın neredeyse tamamına (\% 97) sahip olduğu için New York Borsası analiz dıșı bırakılmıștır. Euronext Borsaları'nın borsa performansını etkileyen sermaye piyasası araçları ve aynı zamanda değerlendirme faktörleri olarak; ișlem günü sayısı (X1), hisse senedi sayısı (X2), yatırım fonları sayısı (X3), borsada ișlem gören fonlar / emtialar / senetler (ETF/ETC/ETN) (X4), yapılandırılmıș ürün sayısı (X5), devlet tahvili (X6), diğer bonolar (X7) ve toplam bonolar (X8) kullanılmıștır. Euronext Borsaları'nın verileri ikincil veri olup, veriler Euronext.com'dan indirilmiștir. Ayrıca araștırmadaki değerlendirme faktörlerinin ağırlıkları MW (Mean Weight: Ortalama Ağırlık) yöntemine göre belirlenmiștir (Diakoulaki vd., 1995).

Vıkor yönteminin tüm adımları tüm yıllar için uygulanmıș; ancak örneklemin son yılı olan 2017 yılı için tüm așamalar yöntemle ilgili bilgilendirme açısından örnek olarak gösterilmiștir.

ilk olarak analizde kullanılacak veri setinden karar matrisi olușturulmaktadır. Karar matrisi Tablo 2'de gösterilmiștir.

Tablo 2. 2017 Yılı Karar Matrisi

\begin{tabular}{|c|c|c|c|c|c|c|c|c|c|c|}
\hline $\begin{array}{c}\text { Euronext } \\
\text { Borsalari / } \\
\text { Kriterler }\end{array}$ & $\mathrm{x} 1$ & $\mathrm{x} 2$ & $\mathrm{x} 3$ & $\mathrm{x} 4$ & $\times 5$ & x6 & $\mathrm{x} 7$ & $\mathrm{x} 8$ & Değișkenler & Ağrrlıkları \\
\hline Amsterdam & 255 & 534022 & 12454 & 18406 & 5406 & 188 & 2390 & 2578 & $X 1=\mid$ ș̦lem günü sayısı & 0,125 \\
\hline Brüksel & 255 & 106485 & 0 & 15 & 84 & 33 & 52 & 85 & $X 2=$ Hisse senedi sayısI & 0,125 \\
\hline Dublin & 255 & 24144 & 0 & 3 & 0 & 0 & 0 & 0 & $\mathrm{X} 3=$ Yatirım fonları sayıs & 0,125 \\
\hline Lizbon & 255 & 23902 & 0 & 28 & 1107 & 1166 & 76 & 1242 & $\mathrm{X} 4=\mathrm{ETF} / \mathrm{ETC} / \mathrm{ETN}$ sayısı & 0,125 \\
\hline Paris & 255 & 1055548 & 1 & 45032 & 3568 & 53 & 2777 & 2830 & $\begin{array}{c}X 5=\text { Yapılandırılmıs ürün } \\
\text { sayısı }\end{array}$ & 0,125 \\
\hline \multirow{3}{*}{\multicolumn{9}{|c|}{$\begin{array}{l}X 7=\text { Diğer bonolar } \\
0,125 \\
X 8=\text { Toplam bonolar } \\
0,125\end{array}$}} & $\mathrm{X} 6=$ Devlet tahvili & 0,125 \\
\hline & & & & & & & & & & \\
\hline & & & & & & & & & & \\
\hline
\end{tabular}


Tablo 2'de 2017 yılının karar matrisi görülmekte ve bu matriste 5 Euronext Borsası, 8 değerlendirme faktörü bulunmaktadır. Değerlendirme faktörlerinin ağırlıkları MW yöntemi kullanılarak belirlenmiștir. MW yöntemine göre ağırlıklar; 1 / değișken sayısı formülüyle hesaplanmakta ve bu çalıșmada ağırlıklar 0,125 (1/8) olarak bulunmuștur.

Araștırmaya ait veri setinden karar matrisi olușturulduktan sonra Vıkor yönteminin ilk adımı olan her bir değișkenin en iyi ve en kötüleri bulunmaktadır. Bu așamaya ait sonuçlar Tablo 3'de gösterilmiștir.

Tablo 3. 2017 Yılı En İyi / En Kötü Değerlerinin Belirlenmesi

\begin{tabular}{|l|c|c|c|c|c|c|c|c|}
\hline Skorlar / Değișkenler & X1 & X2 & X3 & X4 & X5 & X6 & X7 & X8 \\
\hline Maksimum & 255 & 1055548 & 12453 & 45032 & 5406 & 1165 & 2776 & 2829 \\
\hline Minimum & 255 & 23901 & 0 & 3 & 0 & 0 & 0 & 0 \\
\hline
\end{tabular}

En iyi ve en kötü değișkenlerin belirlenmesinin ardından verilerin standartlaștırılarak $S_{\text {, ve }} R_{i}$ değerlerinin bulunması așamasına geçilmektedir. Bu așamada 2 ve 3 numaralı formüllerden yararlanılmaktadır. Formüller sonucu ulașılan skorlar Tablo 4'de gösterilmiștir.

Tablo 4. 2017 Yılı $S_{i}$ ve $R_{i}$ Değerlerinin Belirlenmesi

\begin{tabular}{|l|c|c|c|c|c|c|c|c|}
\hline $\begin{array}{l}\text { Borsalar / } \\
\text { Değișkenler }\end{array}$ & X1 & X2 & X3 & X4 & X5 & X6 & X7 & X8 \\
\hline Amsterdam & 0 & 0,063 & 0 & 0,074 & 0 & 0,105 & 0,017 & 0,011 \\
\hline Brüksel & 0 & 0,115 & 0,125 & 0,125 & 0,123 & 0,121 & 0,123 & 0,121 \\
\hline Dublin & 0 & 0,125 & 0,125 & 0,125 & 0,125 & 0,125 & 0,125 & 0,125 \\
\hline Lizbon & 0 & 0,125 & 0,125 & 0,125 & 0,099 & 0 & 0,122 & 0,070 \\
\hline Paris & 0 & 0 & 0,125 & 0 & 0,043 & 0,119 & 0 & 0 \\
\hline Si & 0,271 & 0,853 & 0,875 & 0,666 & 0,287 & & & \\
\hline Ri & 0,105 & 0,125 & 0,125 & 0,125 & 0,125 & & & \\
\hline
\end{tabular}

Tablo 4'de veriler standartlaștırılıp, verilere ait $S_{i}$ ve $R_{i}$ değerleri bulunmuștur. Bu noktada diğer așamadakinin aksine $8 S_{i}$ ve $R_{i}$ değeri değil 5 değer bulunmaktadır. Çünkü kıyaslanacak alternatif sayısı 5 borsadan olușmaktadır. Bir sonraki adıma geçmeden önce bir sonraki adımda kullanılmak üzere $S$ ve $R$ değerlerinin en iyi ve en kötüleri belirlenmiștir. Sonuçlar Tablo 5'de gösterilmiștir. 
Tablo 5. 2017 Yılı $S_{i}$ ve $R_{i}$ Değerlerinin En İyi / En Kötüleri

\begin{tabular}{|c|c|}
\hline En iyi / En kötü & Skorlar \\
\hline Smak & 0,875 \\
\hline Smin & 0,270 \\
\hline Rmak & 0,125 \\
\hline Rmin & 0,105 \\
\hline
\end{tabular}

Tablo $5^{\prime}$ de $S_{i}$ ve $R_{i}$ değerlerinin maksimum ve minimum değerlerini bulunmuș ve veriler bir sonraki adıma hazır hale getirilmiștir. Diğer adımda $Q_{i}$ değerinin bulunması safhasıdır. Bu adım 4 numaralı formül yardımıyla hesaplanmıș ve $Q_{i}$ değerleri Tablo 6'da gösterilmiștir.

Tablo 6. 2017 Yılı $Q_{i}$ Değerleri

\begin{tabular}{|l|c|c|c|c|c|}
\hline Qj Formülü / Borsalar & Amsterdam & Brüksel & Dublin & Lizbon & Paris \\
\hline$v$ (Si - Smin) / (Smak - Smin) & 0 & 0,482 & 0,5 & 0,327 & 0,013 \\
\hline $1-v(R i-R m i n) /(R m a k-R m i n)$ & 0 & 0,5 & 0,5 & 0,5 & 0,499 \\
\hline$Q_{j}$ & 0 & 0,982 & 1 & 0,827 & 0,513 \\
\hline
\end{tabular}

Tablo 6'da $Q_{i}$ değerlerinin 4 numaralı formülünün açılımı gösterilmiștir. Bu formülde yer alan $v$ değeri 0,5 alınmıș, bunun temel nedeni; istisna olmadığı sürece literatürde kabul gören bir taraf adına dengeyi bozmama kuralıdır. Tablo 6 sonucunda; alternatifler sıralamaya hazır hale gelmiș ve Tablo 7'de gösterilmiștir.

Tablo 7. 2017 Yilı $_{i}, R_{i}$ ve $Q_{i}$ Değerleri

\begin{tabular}{|c|c|c|c|c|c|}
\hline S, R ve Q / Borsalar & Amsterdam & Brüksel & Dublin & Lizbon & Paris \\
\hline $\mathrm{Si}$ & 0,270 & 0,853 & 0,875 & 0,666 & 0,287 \\
\hline $\mathrm{Ri}$ & 0,104 & 0,125 & 0,125 & 0,125 & 0,125 \\
\hline $\mathrm{Qj}$ & 0 & 0,982 & 1 & 0,827 & 0,513 \\
\hline
\end{tabular}

Tablo 7'de $S_{i}, R_{i}$ ve $Q_{i}$ değerleri tüm borsalar için belirlenmiș ve sıralamaya hazır duruma getirilmiștir. Sıralama küçükten büyüğe yapılmakta ve sıralama sonuçları Tablo 8'de gösterilmiștir.

Tablo 8. 2017 Yılı Euronext Borsaları Sıralaması

\begin{tabular}{|c|c|c|c|c|c|}
\hline $\mathbf{S i}$ & Amsterdam & Paris & Lizbon & Brüksel & Dublin \\
\hline $\mathbf{R i}$ & Amsterdam & Paris & Lizbon & Brüksel & Dublin \\
\hline $\mathbf{Q j}$ & Amsterdam & Paris & Lizbon & Brüksel & Dublin \\
\hline
\end{tabular}


Tablo 8' de $S_{i}, R_{i}$ ve $Q_{i}$ değerlerine göre borsalar küçükten büyüğe sıralanmıș ve hangi borsanın en etkin olduğu belirlenmiștir. Sıralama sonuçları; $S_{i}, R_{i}$ ve $Q_{i}$ değerlerinin hepsinde aynı çıkmıștır. Amsterdam Borsası en etkin Euronext Borsası olarak belirlenirken, Euronext bünyesine yeni katılan Dublin Borsası en zayıf olarak belirlenmiștir. Bulunan bu sonuçların kontrolü 2 koșulla test edilmiștir. Birinci koșul 5 ve 6 numaralı formüllerle kontrol edilmiș, sonuçlar Tablo 9'da gösterilmiștir.

Tablo 9. 2017 Yılı Koșul 1

\begin{tabular}{|l|c|}
\hline$D(Q)$ & 0,25 \\
\hline$Q\left(a^{2}\right)$ & 0,513240795 \\
\hline$Q\left(a^{1}\right)$ & 0 \\
\hline$Q\left(a^{2}\right)-Q\left(a^{1}\right) \geq D(Q)$ & 0,513240795 \\
\hline Koșul 1 & Sağlandı \\
\hline
\end{tabular}

Tablo 9'da 2017 yılına ait birinci koșul olan kabul edilebilir avantaj koșulu test edilmiș ve uygulanan formül sonucunda koșulun sağlandığı görülmüștür. Sıralamanın doğruluğunu onaylamak için kullanılan 2. koșulun sonuçları ise Tablo 10'da gösterilmiștir.

Tablo 10. 2017 Yılı Koșul 2

\begin{tabular}{|c|l|l|l|l|l|l|}
\hline $\mathbf{S i}$ & Amsterdam & Paris & Lizbon & Brüksel & Dublin & \\
\cline { 1 - 5 } $\mathbf{R j}$ & Amsterdam & Paris & Lizbon & Brüksel & Dublin & $\begin{array}{c}\text { Q'ya uyum: } \\
\text { Koșul } 2 \text { sağlandı. }\end{array}$ \\
\hline $\mathbf{Q j}$ & Amsterdam & Paris & Lizbon & Brüksel & Dublin & \\
\hline
\end{tabular}

Tablo 10'da ikinci koșul olan kabul edilebilir istikrar koșuluna ait bilgiler gösterilmiștir. Bu koșulda amaç; Q'ya uyum göstermektir. $Q_{i}$ değerinin sıralamasının $S$ ve $R$ değerlerinin en az 1 tanesinde olması $Q$ sıralamasının doğru olduğunu kanıtlamaktadır. Bu çalıșmada $S, R$ ve $Q$ değerleri aynı sıralama sonucunu verdiği için koșul 2 sağlanmıștır.

Vıkor yönteminin 2017 yılı için koșulları da sağladığı görülmüș ve Euronext Borsaları'nın sıralaması; Amsterdam > Paris > Lizbon > Brüksel $>$ Dublin șeklinde gerçekleșmiștir. Tüm yıllar için sıralama sonuçları ise Tablo 11 'de gösterilmiștir. 
Tablo 11. 2004-2017 Yılları Arası Vıkor Sıralaması

\begin{tabular}{|c|c|c|c|c|c|c|c|c|c|c|c|c|c|c|}
\hline $\begin{array}{l}\text { Borsalar / } \\
\text { Yillar }\end{array}$ & ষ্ণ & ઠ̊ & ষ্ণ & ઠิ & ஜ্ণ & ठ্ & 윰 & $\bar{N}$ & $\frac{\text { ก }}{\text { ก }}$ & $\frac{m}{\text { D্ }}$ & $\frac{ষ}{\mathbb{N}}$ & ㅇํํ & 융 & 요 \\
\hline Amsterda & 1. & 1. & 1. & 1 & 1. & 1. & 1. & 1. & 1. & 1. & 1. & 1. & 1. & 1. \\
\hline Brüksel & 4. & 4. & & & 4. & 4. & 4. & 3. & 4. & 4. & 4. & 4. & 4. & 4. \\
\hline Dublin & 5. & 5. & 3. & 3. & 5. & 5. & 5. & 5. & 5. & 5. & 5. & 5. & 5. & 5. \\
\hline Lizbon & 3. & 3. & & & 3. & 3. & 3. & 4. & 3. & 3. & 3. & 3. & 3. & 3. \\
\hline Paris & 2. & 2. & 2. & 2. & 2. & 2. & 2. & 2. & 2. & 2. & 2. & 2. & 2. & 2. \\
\hline
\end{tabular}

Tablo 11 'de 2004-2017 yılları arası 14 yıl için Vıkor yöntemine göre Euronext Borsaları borsa performansları açısından sıralanmıș ve tüm yıllarda Euronext'te Amsterdam Borsası sermaye piyasası araçları açısından en etkin ve en iyi performans gösteren borsa olarak belirlenmiștir. En zayıf borsa ise Euronext'in yeni üyesi olan Dublin Borsası'dır. Sıralamalar bazı yıllarda farklılașsa da tüm yıllar için genel özet olarak Euronext Borsaları; Amsterdam > Paris > Lizbon > Brüksel > Dublin șeklinde sıralanmaktadır. Ayrıca 2006 ve 2007 yıllarında tüm borsalar Vıkor yönteminin koșullarına uyum göstermemiștir sadece Vıkor koșuluna uyum gösteren 3 borsa sıralanmıștır. Bu sıralama da Vıkor yönteminin güvenilirliğini göstermekte ve sıralamada alternatiflerin koșullara uyumu esas alınmaktadır.

\section{Sonuç}

Borsalar ve diğer sermaye piyasası kurulușlarının birleșmesi, devralınması gibi ortaklık türü faaliyetler uluslararası sermaye piyasalarında trend olmaya bașlamıștır. Bunun temel nedeni; artan rekabet koșullarında maliyeti azaltarak karı yükseltmektir. Günümüzde Avrupa'da borsa denilince akla; Euronext, Londra, Norex ve Frankfurt (Deutsche Börse) Borsaları gelmektedir. Bu borsalar hem aralarındaki rekabette ilk sırada yer alabilmek hem de birbirleriyle olan bağlantıları arttırmak için çaba göstermektedir. Bu çabalara, borsalar arası teknolojik ișbirlikleri ortaklığı örnek olarak verilebilmektedir. Ayrıca Euronext'in olușumu ve gelișim süreci, borsalar arası birleșme ve ișbirliği faaliyetlerinde oldukça önem arz etmektedir. Euronext; ișlem maliyetlerini azaltmak ve likiditeyi arttırmak üzere kurulan bir Avrupa Borsası'dır.

Avrupa pazarında önemi giderek artan Euronext'in kendi içerisinde borsaları bulunmaktadır. Çalıșmada Euronext Borsaları'nın seçilme nedeni ise hem Avrupa hem de dünya borsaları arasındaki rekabette en üst sıralarda yer almasıdır. Bu rekabetin Euronext Borsaları içerisinde- 
ki durumu tespit edilerek, hangi Euronext Borsası'nın hangi yılda daha etkin olduğu ve daha yüksek performans gösterdiği analiz edilmiștir. Analiz sonucunda; Euronext Borsası'na en çok katkıyı yapan borsa belirlenmiștir. Katkıyı ölçmek için Euronext Borsaları'nın tümünde kullanılan sermaye piyasası araçları ve ișlem günü sayıları baz alınmıștır.

Araștırmada 2004-2017 yılları arası ikincil veriler yardımıyla 5 Euronext Borsası'nın borsa performansları ölçülmüștür. Bu ölçüm, çok kriterli karar verme tekniklerinin en sağlıklı ve güvenilir olanlarından biri ve finans alanında kullanıma uygun olan Vıkor yöntemiyle yapılmıștır. Vıkor yöntemi sonucunda; Euronext'teki Brüksel ve Lizbon Borsaları'nın 2006 ve 2007 yıllarında yöntemin koșullarına uyum göstermemesi nedeniyle sıralama farklılașsa da genel sıralama; Amsterdam, Paris, Lizbon, Brüksel ve Dublin sıralamasıdır. Bu sıralamayı; Amsterdam'ın Avrupa pazarında gelișimi ve yükseliși hatta Euronext Borsaları içerisindeki en eski borsalardan biri olması gibi özellikleri doğrulamaktadır. Ayrıca Dublin Borsası ise Euronext Borsaları içerisine yeni dahil olduğu için performans açısından oldukça düșük seviyededir. Bu sonuç yatırımcılar açısından değerlendirildiğinde; Euronext Borsaları içerisinde seçim yapmak gerektiğinde ya risk alarak yeni bir borsa olan Dublin Borsası'na yatırım yapılabilir ya da riskten kaçarak geleneksel yatırım düșüncesiyle eski borsalardan olan Amsterdam Borsası'na yatırım yapılabilir. Ancak bu sonuç risk alma derecesine göre farklılık gösterebilmektedir. Piyasalar için ise eski ve oturmuș bir borsanın borsa performansının yenilere göre yüksek olduğu görülmektedir.

Euronext Borsaları'yla ilgili çalıșmalar genellikle farklı borsalarla kıyaslama ve aralarındaki ilișkiyi ekonometrik bir analizle test etme biçimindedir. Hem bu sebeple hem de Euronext Borsaları'nın içerisindeki dinamik yapıyı görmek açısından çalıșmanın literatüre katkı sağlayacağı düșünülmektedir. Çalıșmanın gelișimi açısından ise farklı borsalarla kıyaslanması önerilebilir. 


\section{KAYNAKÇA}

Abarbanell, J. \& Bernard, V. (2000). Is The U.S. Stock Market Myopic? Journal of Accounting Research, 38(2), 221-242.

Akyüz, G. (2012). Bulanık Vıkor Yöntemi Ile Tedarikçi Seçimi. Atatürk Üniversitesi iktisadi ve İdari Bilimler Dergisi, 26(1), 197-215.

Altay Topçu, B. \& Oralhan, B. (2017). Türkiye ve OECD Ülkeleri'nin Temel Makroekonomik Göstergeler Açısından Çok Kriterli Karar Verme Yöntemleri Ile Karșılaștırılması. International Journal of Academic Value Studies, 3(14), 260-277.

Ay Türkmen, M. \& Bildik, T. (2015). Șehirlerarası Yolcu Tașımacılığında Bulanık Vıkor Uygulaması. Manas Sosyal Araștırmalar Dergisi, 4(2), 1-15.

Beltran, H., Durre, A. \& Giot, P. (2004). Volatility Regimes and The Provision Of Liquidity in Order Book Markets. Discussion Papers (ECON-Département des Sciences Economiques) No:2005015, Université catholique de Louvain, Département des Sciences Economiques.

Brodocianu, M. (2015). The Analysis of The CAC 40 National Index and of The Euronext 100 Pan-European Index Using Arch Models. Procedia Economics and Finance, 27, 548-555.

Budak, A. \& Cikot, Ö. (2011). Dünyada Borsa Șirketleșmeleri, Satın Alma ve Birleșmeleri. İstanbul: Türkiye Sermaye Piyasası Aracı Kurulușlar Birliği (TSPAKB) Yayınları (Yayın No: 58).

Chemmanur, T. J. \& Jie, H. (2008). Competition and Cooperation Among Exchanges: Effects On Corporate Cross-Listing Decisions and Listing Standards. Journal of Applied Corporate Finance, 20(3), 76-90.

Coșkun, A. (2002). Vadeli İșlemler Piyasalarında Elektronik Ticaret ve IMKB Vadeli İșlemler Piyasası. Banka: Mali ve Ekonomik Yorumlar, 39(5), 77-91.

Çalıșkan, E. \& Eren, T. (2016). Bankaların Performanslarının Çok Kriterli Karar Verme Yöntemiyle Değerlendirilmesi. Ordu Üniversitesi Bilim ve Teknoloji Dergisi, 6(2), 85-107.

Çikot, Ö. (2008). Borsa Birleșmeleri ve Stratejik Ortaklıklar. Sermaye Piyasasında Gündem, 68(Nisan), 8-18.

Demircanlı, B. \& Kundakcı, N. (2015). Futbolcu Transferinin AHP ve VIKOR Yöntemlerine Dayalı Bütünleșik Yaklașım İle Değerlendirilmesi. Dokuz Eylül Üniversitesi iktisadi ve Idari Bilimler Fakültesi Dergisi, 30(2), 105-129.

Desagre, C., D'Hondt, C. \& Petitjean, M. (2018). Liquidity and The Rise Of Fast Trading Euronext. Financial Econometrics Conference: Market Microstructure, Limit Order Books and Derivative Markets, 13-14 September, Lancaster University Management School, UK.

Diakoulaki D., Mavrotas, G. \& Papayannakis, L. (1995). Determining Objective Weights in Multiple Criteria Problems: The Critic Method. Computers \& Operations Research, 22(7), 763-770. 
Dilbaz, K. (2007). Menkul Kıymet Borsalarının Özelleștirilmesi ve İMKB İçin Bir Değerlendirme. (Yüksek Lisans Tezi). İstanbul Üniversitesi Sosyal Bilimler Enstitüsü Para, Sermaye Piyasaları ve Finansal Kurumlar Bilim Dalı, İstanbul.

Emre, Z. (2005). Euronext. Sermaye Piyasasında Gündem, 34(Haziran), 6-23.

Ertuğrul, İ. \& Özçil, A. (2014). Çok Kriterli Karar Vermede TOPSIS ve VIKOR Yöntemleriyle Klima Seçimi. Çankırı Karatekin Üniversitesi İktisadi ve İdari Bilimler Fakültesi Dergisi, 4(1), 267-282.

Euronext, (2019). (2019, 10 Ocak). Erișim Adresi: https://www.euronext.com/en.

Fertekligil, A. (2000). Türkiye'de Borsanın Tarihçesi. İstanbul: IMKB Yayınları.

Floros, C., Jaffry, S. \& Lima, G. V. (2007). Long Memory in The Portuguese Stock Market. Studies in Economics and Finance, 24(3), 220-232.

Hamurcu, C.. \& Aslanoğlu, S. (2013). New York Menkul Kıymetler Borsası (NYSE) İle İstanbul Menkul Kıymetler Borsası (IMKB) Arasındaki Etkileșim ve Her İki Borsada İșlem Gören Turkcell Hisse Senetleri Arasındaki İlișki. Manas Sosyal Araștırmalar Dergisi, 2(3), 27-48.

Isola, M.-N., Teixeira, F. \& Ferreira, F. (2014). Initial Underpricing and The Euronext Lisbon-Listed Companies. Procedia - Social and Behavioral Sciences, 110, 1116 1123.

Karaatlı, M., Ömürbek, N. \& Köse, G. (2014). Analitik Hiyerarși Süreci Temelli Topsis ve Vıkor Yöntemleri İle Futbolcu Performanslarının Değerlendirilmesi. Dokuz Eylül Üniversitesi Iktisadi ve İdari Bilimler Fakültesi Dergisi, 29(1), 25-61.

Kırca, İ. (2000). Hukuki Yönüyle Borsa Opsiyon İșlemleri. Ankara: Banka ve Ticaret Hukuku Araștırma Enstitüsü.

Lee, R. (1992). What Is An Exchange? A Discussion Paper, London: Capital Markets Forum: Section on Business Law, International Bar Association.

Matos, P.-V. \& Coelho, M. (2016). Short-Termism in Euronext Lisbon: An Empirical Analysis. European Journal of Management Studies, 21 (1), 49-75.

Opricovic S. \& Tzeng G.-H. (2004). Compromise Solution By Mcdm Methods: A Comparative Analysis of Vıkor and Topsis. European Journal of Operational Research, $156,445-455$.

Opricovic, S. (1998). Multicriteria Optimization of Civil Engineering Systems. PhD Thesis, Faculty of Civil Engineering, Belgrade.

Ömürbek, N., Karaatlı, M. \& Yetim, T. (2014). Analitik Hiyerarși Sürecine Dayalı TOPSIS ve VIKOR Yöntemleri İle ADIM Üniversitelerinin Değerlendirilmesi. Selçuk Üniversitesi Sosyal Bilimler Enstitüsü Dergisi, Dr. Mehmet Yıldız Özel Sayısı, 189-207.

Özden, Ü.-H. (2012). AB'ye Üye Ülkelerin ve Türkiye'nin Ekonomik Performanslarına Göre Vıkor Yöntemi İle Sıralanması. İstanbul Ticaret Üniversitesi Sosyal Bilimler Dergisi, 11 (21), 455-468.

Paksoy, S. (2015). Ülke Göstergelerinin Vıkor Yöntemi İle Değerlendirilmesi. Ekonomik ve Sosyal Araștırmalar Dergisi, 11 (2), 153-169. 
Plantinga, A. \& Scholtens, B. (2001). Socially Responsible Investing and Management Style Of Mutual Funds in The Euronext Stock Markets. Journal of University of Groningen, Netherlands.

Pownall, G., Vulcheva, M. \& Wang, X. (2011). The Post-Merger Segmentation of Euronext: A Solution To The Inadequacy of National Securities Regulators? Social Science Research Network.

Seymen Oskay, C., Alıınıșık, İ. \& Çakmak, Y. (2006). Avrupa Birliği Sermaye Piyasalarında Görülen Entegrasyon Çalıșmaları ve Türkiye'deki Sermaye Piyasalarının Uyumu. Selçuk Üniversitesi Karaman Iktisadi ve Idari Bilimler Fakültesi Dergisi, 10(9), 181-197.

Tezergil, S. (2016). Vıkor Yöntemi İle Türk Bankacılık Sektörünün Performans Analizi. Marmara Üniversitesi İktisadi ve İari Bilimler Dergisi, 38(1), 357-373.

Than, N. (2017). Intraday Price Clustering in The Euronext Stock Market. 24th Annual Global Finance Conference, 4-6 May, Hempstead, New York, USA.

World Federation of Exchanges, (2018). (2019, 09 Ocak). Erișim Adresi: https:// www.world-exchanges.org/our-work/statistics.

Yavuz, N. \& Baki, B. (2019). Patent Değerlerinin Çok Kriterli Karar Verme Yöntemleri İle Sıralanması: Otomotiv Sektöründe Bir Uygulama. Karadeniz Teknik Üniversitesi Sosyal Bilimler Enstitüsü Sosyal Bilimler Dergisi, 9(17), 27-52.

Yıldırım, B.-F., Kuzu, S. \& Özdemir, M. (2016). Bulanık VIKOR Yaklașımı Ile Mobil İșletim Sistemlerinin Değerlendirilmesi. Afyon Kocatepe Üniversitesi Sosyal Bilimler Dergisi, 18(1), 79-95. 
